\title{
United States: \\ A Review of the US Middle East Policy from Harry Truman to Bill Clinton
}

\author{
Kardo RACHED \\ Salam ABDULRAHMAN
}

\begin{abstract}
Since the Second World War, the Middle East has been mentioned in connection with the national interest of America manifested by US presidents. This paper looks at the US foreign policy in the Middle East from Truman to Clinton on the premise that the US foreign policy has contributed to creating a breeding ground for dissatisfaction toward the US In this context, the paper focuses on the doctrines in use from the time of President Truman to Clinton. Thus, every American president has a doctrine, and this doctrine tells what political line the president follows regarding domestic and foreign policies.
\end{abstract}

Keywords: Middle-East, Israel, US national interest, Soviet Union, Natural resources, ideologies.

Kardo RACHED

Sakarya University, Turkey

E-mail: kardo.mohammad@ogr.sakarya.edu.tr

Salam ABDULRAHMAN

University of Human Development, Iraq

E-mail: salam.abdulqadir@uhd.edu.iq

Conflict Studies Quarterly

Issue 34, January 2021, pp. 45-65

DOI: $10.24193 / \mathrm{csq} .34 .3$

Published First Online: 05 January /2021

\section{Introduction}

In the wake of the Second World War (WWII), the United States of America (US) started showing interest in the Middle East. With Harry Truman's uncompromised support for the newly created state in Palestine, Israel, the Middle-East became an essential part of the US global policy. The US isolation policy that advocated non-involvement in the European and Asian conflicts and nonentanglement in international politics during the 1930s, gave space to Britain, France, and Germany to act actively and independently in the Middle East. However, the dev- 
astating economic consequences of the WWI and its impact on the US economy pushed the policymakers in this country to rethink their isolationist policy. In the aftermath of WWII, a radical change occurred in the USpolicy towards the Middle- East to preserve its vital security interests there. Three essential pillars have played a crucial role in the US Middle East post-war policy:

1. Preventing the Soviet threat and its impact on the region,

2. Keeping Israel secure,

3. Maintaining stability in the area to ensure oil flow to the US and the West.

\section{The Concept of Civilisation and American Foreign Policy}

The 20th century can also be called the American century. In the second half of the $20^{\text {th }}$ century, the US became dominant in world politics and the global economy. US dominance was based on a combination of economic, political, and military power and on an ideology that the US stands for values that the world should take to heart. To recall ex-president George W. Bush after the 11/9/2001 assault, who said:

"There is a value system you cannot compromise with, and it is the values we salute. Moreover, if these values are good enough for our people, they should also be good enough for others, not to impose it because they are God-created values. They are values of freedom and human rights and maternal love for their children (Andersen, 2003, pp. 46-47)".

The American power in the second half of the $20^{\text {th }}$ century was used to promote American values worldwide, first in a showdown with Nazism and Japanese militarism, then with communism. It has indeed been the US self-perception that they must subjugate the non-civilized areas and give them part of American values (Rose, 2000). As George W. Bush said in the presidential campaign in 2000, "Our nation is chosen by God and commissioned by history to be a model to the world" (Nielsen, 2003).

During the Cold War, American politicians managed to convince many traditionally isolationist (Nye, 2014) Americans that communism was a threat to the American way of life. We may also remember that America helped to motivate European counties after WWII to establish a military alliance to defend their common interests. In 1948, this alliance was first called the Western Union and later became known as NATO (Yost, 2014). International responsibility and participation in NATO were observed reverse order the US wanted to make the world safe, but also because it was part of US selfdefence program and foreign policy. There was a radical change in American security and Middle East policy when Ronald Reagan came to power because Reagan's view was that the war against communism must be won at any cost. Therefore, the war against communism had priority over all other things. 
Since the Second World War, the US government has faced many problems in the Middle East, among which was the continuing conflict between the Zionist state in Palestine and the Arab states. This conflict was the reason why the Arab world became divided between conservative and radical states. In 1945, when the European influence was still active in the region, the Arab countries were led by conservatives. However, in the following decades, the power was taken over by radical forces in Syria (1949), Egypt (1952), and Iraq (1958). In the middle of the 1960s, Palestinians in exile founded the group known as the Palestinian Liberation Organization (PLO), which aimed to work for the formation of a Palestinian state (Spiegel, 1985).

Following this, the US government developed three primary objectives in the Middle East. First, it defended the right of Israel to exist. Behind this attitude were mainly domestic political pressure, humanitarian and theological terms, and the need for a reliable strategic ally in the region. Second, it supported peace in the region on the assumption that war and unrest would allow the Soviet Union to gain political or military influence. Finally, the US continually sought to reduce the spread of revolutionary Arab nationalism for the sake of Western strategic and economic interests, including access to oil and preventing Moscow from gaining political influence (Rubin, 2002). Faced with the power balance that existed between Israel, the conservative Arab states, and the radical Arab states, the US policies often sought to strengthen both Israel and the conservative Arabs.

\section{Truman and Eisenhower's Middle East policy}

The first US President to recognise Israel as a state was Harry Truman. On May 14, 1948, after an eleven-minute meeting with the Zionist leaders, he officially announced his recognition of the new state. The president participated as a facilitator when Israel was founded during his first presidential term. In August 1945, he publicly supported the Zionist claim that 100,000 Jewish refugees should be allowed to immigrate to Palestine, at the same time thousands of Palestinians were forced to leave their homeland. After the presidential election in 1948, Truman pledged the US support for Israel and granted a loan of $\$ 90$ million (Bar-Siman-Tov, 1998). His support for Israel was the cause of the worsening of the US relationship with the Arab governments and those who opposed the extensive immigration to the Jewish state in Palestine. For the first time, terrorists carried out a bomb attack on the American theatre in Cairo, in which five people were killed. Truman's support for Israel also challenged the Arab nationalist ideology and attracted a great sentiment of anti-Americanism. Thus, the US was seen as a Neo-Colonial power, replacing the old European colonialists.

After Truman, Eisenhower came to power at a time when the centre of gravity in the US-Soviet rivalry moved to the Middle East thanks to the Nasser who was the president of Egypt with a pan-Arabism ideology depicted the Western countries and the US as 
the main reason for the Arab nation's backwardness (Robby, 2020). Then, Eisenhower needed to convince the Arabs that the US policy was impartial and neutral, while at the same time, he was trying hard to placate the Arab states so much that they would refrain from providing facilities to the Soviet Union. It was clear that unrest would lead to a weakening of Western influence in the region and possibly increase Soviet influence (Spiegel, 1985). In March 1957, Eisenhower pledged financial aid and troop support to friendly governments in the Middle East, especially those threatened by the Soviet Union's expansionist foreign policy. The doctrine was intended to:

1. Prevent Moscow from gaining a foothold in the Middle East,

2. Placate growing nationalism and control modernisation, and

3. Maintain access to oil and otherwise stabilise the region (Yaqub, 2006).

The problem with Eisenhower's doctrine was that it gave the US the right to interfere in the entire region with no regard for the Arab National sovereignty. His doctrine did not improve US relations with the Arab world because the doctrine was utterly contrary to Arab interests. There was widespread support in the Arab world for the Egyptian leader Nasser, Israel's primary opponent. He led a media campaign against the conservative states of the Arab world, such as Jordan and Saudi Arabia. There was a popular rebellion against King Hussein, and the rebels were about to overthrow his regime. However, Eisenhower sent $\$ 10$ million as emergency aid and moved the US Navy to the Mediterranean to prepare for a possible military intervention in Jordan. Jordan was essential for the United States because King Hussein had a moderate policy towards Israel, and he was against nationalism (Spiller, 1981).

\section{John F. Kennedy and Arab nationalism}

The American relations with the radical Arab states were beginning to improve during the presidential term of John F. Kennedy, who had a subjective understanding of Arab nationalism. He was the first president who was seeking a rapprochement with Nasser by sending diplomats to Cairo. The Arabs initially rejected his plan for the Middle East because he proposed to finance the settlement of Palestinian refugees in Iraq and Syria. The proposal, which was justified by Israel's overpopulation problems, looked like an Israeli plan. As the mid-term elections of 1962 approached, Kennedy eased the US pressure on Israel, and the refugee crisis remained unresolved (Spiegel, 1985).

\section{Richard Nixon and the Cold War}

When Nixon came to power, the USA was not as secure compared to a few years earlier because of the US Vietnam policy. The US withdrawal from Vietnamin the early 1970s resulted in the US becoming weaker in the fight against China and the Soviet Union. US influence over its closest allies in Western Europe and Asia was also lower during the 1960s. Western Europe had achieved stability and prosperity and was economically 
and politically less dependent on the US. The Japanese economy was also revived, and Japanese exports began to rival many US products (Roslyng-Jensen, 2003) It was also clear that the US and Western Europe were, from the beginning of 1960, dependent on oil from the Middle East. The Nixon administration saw the Middle East's problems through the prism of superpower issues.

Nixon and his national security adviser, Henry Kissinger, used the Middle Eastern states as pawns in their global chess game with the Soviet Union. Nixon and Kissinger dealt with Israel as a vital element in US strategy, and they approved the irregular borders as they oversaw the Six Days War and provided Israel with military equipment (Ashton, 2007). Israeli concessions to the Arabs appeared (to Kissinger) as a US abandonment of the struggle against the Eastern Bloc.

\section{Jimmy Carter and the Camp David Agreement}

There is no doubt that Jimmy Carter was the first American president who used all his energy and time to achieve peace in the Middle East. President Sadat of Egypt was posed to sign two agreements, one of which declared peace between Egypt and Israel and laid out a timetable for Israeli withdrawal from Sinai. The second gave essential guidelines for the transfer of power in the West Bank and Gaza for the local population. Arab criticism was that Egypt gave up the most and it gave Israel peace in return for a territory that legally was its own, without achieving anything for the Arab countries. The agreement was a significant success for Israel, which had peace with Egypt and secured US promises of the supply of arms and oil, without having to make real concessions in the West (Spiegel, 1985). When Carter was in power, the US lost one of its most important allies in the Middle East: Iran. A regime change in Iran was a significant loss to the United States, and the Carter administration was afraid of an even more significant Communist penetration in the region. However, when the Soviet Union began the invasion of Afghanistan, the Carter administration saw an excellent opportunity to weaken the Communist armies in this war through the Afghan rebels. Therefore, the US government chose to support the Islamic movement, which was started in order to combat communism in Afghanistan. The US-Afghan strategy led to new cooperation between the US and Pakistan. Pakistan was thus a new ally for the US and a central location for the United States, which could manage the Afghan conflict there (Galster, 2001).

\section{Ronald Reagan and the fight against Communism}

Ronald Reagan was elected US president in November 1980 at a time when the relations between the superpowers were getting worse. The Soviet Union carried out in 1978-80 a series of political and military progressions in Africa and Asia, and the US responded through political moves and arms supplies. Soviet aggression in Afghanistan and an 
Islamic fundamentalist revolution in Iran resulted in the Ronald Reagan administration giving up peace to concentrate on defending the Middle East against Soviet and Iranian influence (Spiegel, 1985). Reagan looked great in regional conflicts, and this is what he wanted, to protect American interests by building a strategic consensus between Israel and the Arab states from Egypt to Pakistan (Cobban, 1989). To build strategic consensus, he assisted friendly governments in Turkey, Pakistan, Egypt, Saudi Arabia, Israel, and Jordan.

It was Reagan's view that the Soviet Union would have access to oil in the Arabian Peninsula and he would do anything to destabilize the situation in Afghanistan to help mujahedeen against communism. Pakistan got a new supplier for helping the anti-Soviet partisan movement in Afghanistan.

Lars Andresen, a Danish professor, notes in his book that Reagan carried out real politics (realpolitik) as the USwas about to find alliance partners in South Asia and the Middle East in the struggle against communism (Andersen, 2003). There were different organisations in Saudi Arabia, which sent young Muslims to holy war in Afghanistan, where the young people were strictly trained to fight against communism and received financial help from the King family in the Gulf countries. The United States also supported mujahedeen with different weaponry, and the CIA also played a very significant role in the war with their agents (Andersen, 2003). According to Zachary Lockman, when the young Muslims returned to their home countries, they felt that they had defeated the Soviet Union, who was one of the superpowers of the world. Therefore, they felt that they were now able to overthrow their corrupt regime and maintain an Islamic state. However, this dream was never fulfilled, and many of them met stiff resistance from their government. Gradually, it became clear to the young Muslims that the United States had supported their corrupt home regime, and, therefore, many of them chose to direct their hatred and frustration towards the US and joined Al-Qaida under the leadership of Osama Bin Laden (Lockman, 2004).

\section{Reagan's relationship with Iran after the Shah's Fall}

Iran had a good relationship with both the US and Israel before the Shah's fall in December 1978, and a keen Iran for keeping their relationship with the US was considered to be in the US interests (Simbar, 2006, pp. 76-78). This interest in Iran was due to the country's neighbour, Iraq, which was under a nationalist government, and Iraq was more open to the Soviet Union. Conservative regimes were given an even more significant role in US policy after clerics ruled Iran. There was also a high risk that Iran would export the revolution to the entire region. Iraq went to war against Iran to stop the Iranian influence in Iraq and a Shia revolution in the region. Thus, there was an opportunity for Reagan to shift US support from Iran to Iraq because Iraq was in combat against the Iranian regime. Iraq came into this significant role after the clerics 
overthrew the Shah's regime. This shift in US Middle East policy was crucial for Reagan because he could preserve peace and stability in the region and ensure the flow of oil into the West. Many people ask today why the United States and the West did not respond when President Saddam Hussein of Iraq attacked the Kurds with chemical weapons. The answer is that Saddam's regime at this time was more important for the US than anything else, and as a result, the US was forced to support a dictatorial regime like Saddam's (Andersen, 2003).

\section{The US Middle East policy during the Cold War}

The US foreign policy can be analysed from two different school perspectives: realism and idealism. In realism, power has the priority overvalues and ideology, and power is the key to stability and security, but in idealism, there is an emphasis on the need for achieving peace and security (Andersen, 2003). The Cold War divided the world between the US and the Soviet Union and their respective allies in what has subsequently been called the bipolar world order. These two superpowers were representing each of their different ideologies.

I have chosen to start from the Truman doctrine because of his doctrine, in my opinion, is the foundation of American foreign policy during the Cold War. The Truman Doctrine provides the framework for the Cold War regarding who the enemy is and what the US role would do about this enemy. It stated:

"One of the primary objectives of the foreign policy of the United States is the creation of conditions in which we and other nations will be able to work out a way of life free from coercion. We shall not realize our objectives, however, unless we are willing to help free peoples to maintain their free institutions and their national integrity against aggressive movements that seek to impose upon them totalitarian regimes. This is no more than a frank recognition that totalitarian regimes imposed upon free peoples, by direct or indirect aggression, undermine the foundations of international peace, and hence the security of the United States" (Anders, Fredrik, Oyyind, \&Torbjorn, 2008, p. 335).

It can be inferred from the Truman Doctrine that the US' interest is to fight causes that threaten their interest in the world and their safety as a nation. The US considers communism a threat that will challenge US power in the international system. The background of the US perception of communism as a threat, arises from ideological differences. Communism hinders the spread of American capitalism as an ideology, and the US has an economic incentive to fight communism. This threat will be realized by a promise of US military aid to countries that are threatened by communism, as was the case in Greece and Turkey, which received financial assistance (Branner, 2002). After the Second World War, the Middle East became strategically and economically important for the United States. In 1931, the California millionaire and globetrotter 
Charles R. Crane visited Saudi Arabia, which led to negotiations with the new kingdom and with the oil companies with a conclusion of a 60-year contract to extract oil in the Gulf. The agreement was signed in 1933, and in 1939, the transporting of Saudi oil to the US began through the Saudi Arabian company Aramco (Andersen, 2003). Up to 1947, US interests in the area were so little that the US did not even have an ambassador in Riyadh.

However, with the development of the first Cold War and the American Containment policy towards the Soviet Union, the area grew not only economically but also became politically and strategically important for American foreign policy. At this time, the seven major oil companies, called the Seven Sisters, had secured full control of Arab oil. In 1950, the Seven Sisters became responsible for $99 \%$ of oil production in the Middle East and $50 \%$ of the worldwide production (Gettleman \& Schaar, 2003). The Second World War was followed by a period of rapid economic development in industrialised countries increased private car production in Europe and particularly in the US It resulted in the need for oil doubled in the period 1950-1965, and oil was expected to be an efficient and clean energy resource, which was preferred over coal.

However, the great powers' influence started to diminish. For example, the United Kingdom (UK) faced many economic problems after the Second World War, and it was difficult for the UK to keep its position as a colonizer in the Middle East. It no longer had the resources needed to retain control of the Middle East. Therefore, the UK was not able to maintain its power over Palestine; hence it handed it over to the UN. This resulted in the US taking over the western influence in the area fearing that it would fall into the hands of the Soviet Union. The United States wanted the Middle East to be part of the global anti-Soviet defence, aimed at blocking communism so that it would not expand.

US involvement in the Middle East had as its purpose that the Soviet Union would not gain control over the vast oil reserves. It happened at the same time that oil had a vital importance for US industrial production and economic and technological development. US interests in the Arab region's oil resources have resulted in their direct involvement in the region. During the first oil crisis, the then American Secretary of State, Henry Kissinger, said that the US would not rule out the use of force. They threatened to intervene militarily in the Arab countries if they limited the Western world by limiting oil availability (Bowcott, 2004).

The fact that US oil consumption was the largest in the world and the most massive oil deposits are present in the Middle East makes oil one of the primary determinants of US involvement in the area. In this context, free access to oil is a vital interest to the United States, mainly to prevent the Soviet Union from gaining more power around the world. 


\section{US military presence}

Another critical aspect of the US Middle East policy is that the US has a keen interest in maintaining stability in the region so that oil flows unimpeded through the Arabian Gulf. The US and Saudi Arabia reached an agreement in 1945, observing military protection for Saudi Arabia in return for the United States having priority access to its oil sources (Rubin, 1979). With direct military support to the Saudi Arabian royal family, the US cemented its influence in the country. The agreement created a symbiosis that developed the US military presence into a necessity for both the US and Saudi Arabia. Symbiosis can be seen in the Saudi royal family who needed the US support and presence to stay in power, and the US has agreed to military protection to maintain their necessary oil supply. The main reason that the United States did not want to remove the Saudi royal family from power was fear of unrest and instability in the oil-rich area. At the same time, we must also remember that Wahabism also had a significant role in this agreement between the US and Saudi Arabia. For example, part of the agreement included that religious leaders would not interfere in national politics, and their only request from the Royal Family was that the Constitution should have an Islamic basis. However, this picture has changed after the Iraq-Kuwait war and especially after the Saudi royal family offered military bases to the American armies.

Another primary reason for excessive anti-American sentiments in the Arab World is the US handling of the conflict between Israel and Palestine. Since the creation of Israel in 1948, Israel has received crucial financial support from the US, and in the period from 1948 to 1988, Israel received an overall US contribution that amounted to $\$ 65$ billion. Although a significant proportion of aid was in the form of military aid, in 1983, Israel got an economic aid amounting to $\$ 487.50$ per capita, while other countries in the region received far less, such as Egypt which received $\$ 23.28$ per capita (Zunes, 2002). Besides providing Israel with direct economic and military aid, the US has also supported Israel in the following vital areas:

- Israel has free access to the most advanced military technology and Intelligence.

- Israeli producers are allowed to compete with US producers, mainly in NATO and in the third world.

- Investment in an Israeli equipment

- Include Israel in Strategic Defence Initiative (SDI) research program.

- Direct the majority of US embassies around the world to help the Israelis to promote Israel's political and economic influence

- Israel is still the country in the world which receives the most exceptional support from the US, in the form of American military and economic support (Andersen, 2003, p. 113). 


\section{The underlying interests of US support for Israel}

No other state and no Arab country have ever had such an intimate, distinctive relationship to the internal political process in the US as Israel. This is partly due to the American Jewish community, who is willing to make an extraordinary effort to help the state of Israel and disseminate a pro-Israeli opinion across the American society as reflected in the US Congress and successive administrations. Approximately two-thirds of the world's Jews live in Israel and the United States. There is a deep connection between Israel's 3.4 million Jews and the 6.6 million US Jews (Nauntofte, 1987). It is the Jewish community in the US who is the real impetus for the unique relationship between the US and Israel. At the same time, a significant majority in Congress, which has always been willing to provide Israel with generous financial support and weapons, has always been supported by pro-Israeli lobbying organizations.

The Jewish lobby in the US is an influential factor in American foreign policy in connection with Israel. An organization like the American-Israel Public Affairs Committee (AIPAC) is today the most powerful lobby in Washington, which, due to its enormous economic resources, can lead a reasonably simple but very effective strategic plan. The strategy is to finance the election campaign of a candidate for Congress and then, if he/ she is elected, to try to promote AIPAC's issues through powerful presence. Lars Erslev Andersen has written in his book, "For an American politician who has received campaign funds from AIPAC, it can be extremely harmful to the candidate to put themselves out with AIPAC" (Andersen, 2003, p. 140).

A concrete example of the Jewish lobby power appears during Clinton's administration. The Clinton administration included several eminent people who were under strong influence from AIPAC.

Furthermore, the Jewish community in the US in 1992 contributed to $60 \%$ of Clinton campaign funds, and $80 \%$ of American Jews voted for Clinton in that presidential election. That gave Clinton an insufficient ability to push Israel into the peace processes that he worked hard on. In April 1998, AIPAC wrote a letter to Clinton, where they appealed to him, saying that he was not pushing the Israelis in peace talks in London. The letter was signed by 81 of the 100 senators (Andersen, 2003).

The US has historically condemned the Jewish settlements in the occupied Palestinian territories, but it has never imposed direct sanctions on Israel. Moreover, when Israeli settlements spread beyond the region to integrate some of the areas in Israel, it was the American taxpayer who paid to finance that process of illegal restructuring of settlements. It is because of this that the reluctance to support the United States is rapidly increasing in all Arab countries (Chomsky, 2003). Another reason for US support for Israel can be seen as a result of the security interests in the Arab region during the Cold War. The following four points indicate what objectives US foreign policy was prone 
to foster:

1. Enhance US national security and its international role and prestige

2. Facilitate US access to world markets and essential natural resources (including energy)

3. Match the Soviet military and political influence around the world and undermine the communist economic and political systems

4. Maintain Israel's military superiority over Arab countries

These points were put forward in 1988 when the Soviet Union was still strong enough to threaten the national interests of the United States. Paragraph three shows US security interests about the promotion of American values in Israel. This point was very relevant during the Cold War when the United States saw communism as its most significant threat. In particular, Ronald Reagan led the security policy, as Lars Andersen describes it, as a conservative civilization approach aimed at combating civilizations that threatened their culture and tradition, including war. Therefore, a secure Israel, and thus, ironically, an entire secure region, would have projected American values, which was needed as a bulwark against communism. Paragraph 4 is a natural extension of this idea but also an expression of the Israeli lobby in the US Section, to illustrate how the US acted as hegemony.

Nevertheless, there is a religious dimension to this issue, too. There are biblical and historical reasons for the goodwill that Israel enjoys. There is a feeling of guilt because of the fate of the Jews in the Holocaust. For the Christian Zionists in the US (the Republican right-wing), it is also about helping the Jews rebuild the Temple in Jerusalem because it would open the way for the Second Coming of the Messiah (Andersen, 2003).

\section{The New World}

The US Middle East policy after the Cold War and the Soviet Union's capitulation in 1989 changed the world system from Bipolarity to Uni-polarity. Thus the United States returned to being the sole superpower in the world. This led to the US role in the Middle East to get a new meaning. This was built on the fact that all other countries in the world system now had to take into account the United States, without the possibility of allying with another superpower. US interests could now be managed without regard to the threat that the Soviet Union had previously posed against them (Herrmann, 1994).

After the Cold War was over, opportunities disappeared in the Middle Eastern Arab countries to seek the support of a superpower in the fight against US-supported Israel. As a matter of fact, these countries had to engage in dialogue with the United States. As the United States ceased to be the sole superpower in 1991, there was a peace process between Israel and a few Middle Eastern Arab countries. The new world system led those Arab countries to realize that they cannot make peace on their own because, 
with the United States as the sole superpower, they had to seek other ways, such as negotiation.

George H. W. Bush, Sr., launched the term New World Order on 1 October 1990 in his speech to the UN General Assembly. In that speech, he primarily described the arrangements which the UN had made against Iraq because of Iraq's occupation of the neighbouring state of Kuwait. However, the main speech was a vision of creating a new world with the help of the UN. The goal was to increase democracy and prosperity and to reduce militarization, which would have been achieved through international and regional organisations (Branner, 2002).

George H.W. Bush Senior described the objectives of Congress, on 11 September 1990 as follows:

"Out of these troubled times, our fifth objective - a new world order - can emerge a new era - freer from the threat of terror, stronger in the pursuit of justice and more secure in the quest for peace. An era in which the nations of the world, East, and West, North and South, can prosper and live in harmony" (Ougaard, 1992, p. 141).

The quote is from an article in the Washington Post which appeared immediately after Iraq invaded Kuwait and expressed a vision in which East and West, North and South, were united in peace and harmony. The United States saw itself as the natural leader in this context "... the United States remains the only state with genuinely global strength, reach, and influence in every dimension (Ougaard, 1992, p. 142)".

\section{The Powell Doctrine}

Colin Powell was the US Chief of Staff during the military intervention in Iraq before Operation Desert Storm, and he formulated his doctrine to the US defence and government. Powell's doctrine implied that the US should limit its military interventions into those conflicts, which he saw as easily overcome quickly and richly victorious. This perspective included that the military interventions must be done by using sufficient military force, which would ensure minimal casualties within the Americans military establishment. An involvement would have required broad popular support and a clear focus. This doctrine could be viewed in light of Americans' traumatic experiences from the Vietnam War (Olsen, 1991).

The Powell doctrine has been the benchmark for how the US has led war since its formulation. The doctrine was implemented for the first time in 1991 during the Kuwait war and later in Kosovo in 1999. In 1991, during the Gulf War, it was a very successful strategy, since the war was short. In Kosovo, it was used in this respect when the US conducted air bombardment. By managing to limit the duration of the war, the US forces were successful in avoiding the loss of lives and thus confirmed the premise. To that 
effect, America could allow itself to formulate a document such as the Powell Doctrine that can be considered a result of a long standing emphasis on the military.

A few years after the Cold War ended, despite significant multilateral opportunities, the election of George H.W. Bush Senior led the US to emphasise the selectivity of their military commitment. This policy of selectivity demonstrated that the United States, through its foreign policy line, gave more weight to its military than to international cooperation.

In August 1990, Iraq invaded the neighboring state of Kuwait due to economic reasons. Iraq announced that Kuwait had exceeded its oil production quota agreements, which were managed via OPEC. Excess production had resulted in a decrease in the oil price, which badly affected Iraq since the country's only export source was oil. The low income had a substantial impact on Iraq because the country's reconstruction after the 8-year war against Iran from 1980-1988 was costly. Iraq also believed that Kuwait drilled Iraqi oil in Rumaillah oil field (Al-Sabah, 1990). A stable flow of cheap oil from the Middle East was vital for the United States to maintain or strengthen its capability, which was strong technologically and ineffective in weapons manufacturing. According to Neorealists' theory, the military force is the primary magic factor in international politics, and this is based on state capability, which ensures the oil resources to the industry. Therefore, the US' military capability is built on their weapons competitiveness compared to other states.

The US has, like many other Western countries, their own production of oil, but production is costly compared to oil imports from the Middle East (Jerichow, 1993). It is in this context, and one can see the Gulf War as an expression of oil interest affecting the US On 8 August, President Bush, Sr. declared that America would send troops to Saudi Arabia and the Persian Gulf under the code name "Desert Shield". It was stressed by the President that "our troops' mission is purely defensive... They will not begin hostilities, but they will defend themselves, the Kingdom of Saudi Arabia, and other friends in the Persian Gulf" (Olsen, 1991, p. 60). The president tried to outline US interests in the crisis: "Our jobs, our lifestyles, our freedom, and freedom of Western-minded countries everywhere will suffer if control of the world's enormous oil reserves falls into the hands of this man, Saddam Hussein" (Olsen, 1991, p. 61).

This crisis could have moved the balance of power in the world because if Iraq took over Kuwait, they would have had a very significant percentage of the world oil resources and thus could have pushed out the West. It would have weakened the US power in the region and also their control of oil resources. Therefore, it is not difficult to answer the question of whether it was Kuwait's 2 million inhabitants or the oil resources that the US was interested in liberating. 
On 8 November 1990, George Bush, Sr. said that the US would send 200,000 more soldiers to Saudi Arabia. From August to November, the US strategy was to build an international coalition against Iraq. The transition from a defensive to an offensive strategy is primarily found in that Washington slowly became aware of the extent of the enormous war machine that Iraq possessed. The CIA and other Western intelligence services have, for years, had a secure knowledge of the vast store of Iraqi arms, including weapons of mass destruction (Olsen, 1991). After the collapse of Eastern Europe and the Warsaw Pact in 1989, the US military establishment, like other Western countries' defence, realized that the so-called "ascending" regional powers in the Third World could upset the existing balance in the world. The perception was formulated by the US Army Chief of Staff, General Carl E. Vuono, who wrote in April 1990:

"The proliferation of advanced military capabilities has given an increasing number of developing countries in the developing world the ability to wage sustained, mechanised land warfare. The United States cannot ignore the expanding military power of these countries, and the army must retain the ability to defeat potential threats wherever they occur. It could mean confronting with a well-equipped army in the Third World" (Klare, 1992, p. 134).

Based on the quote mentioned above, and on similar studies from other US military personnel, we can hardly doubt that a critical objective for the US transition to the offensive strategy was to curb a potential high power in the Third World. During the crisis, it came to be clear, however, that the United States, Israel, and Western countries feared the large Iraqi army. Therefore, the destruction of Iraq's aggressive capacity was crucial.

The US could remove Saddam Hussein, but they did not, because they did not want him to be replaced by another leader who might have taken the region to further instability. Instead, the Americans were trying to destroy Iraq's production of chemical and biological weapons and their attempts at developing nuclear weapons, probably because they feared an Iraqi attack on strategically important countries such as Israel, Kuwait and Saudi Arabia.

\section{US policy in the Middle East after the Gulf War}

After the Gulf War, it was apparent that the US had to focus on peace around Israel. Iraq had tried to drag Israel into the conflict by attacking Israel. In this way, President Saddam Hussein hoped to get the Arab world's support. Israel was warned that it could not repay Iraq's attacks with Scud missiles, as it was believed that it would gain Iraq the support of the Arab countries (Andersen, 2003). It was clear to the US that he Israel-Palestine conflict should be resolved to ensure stability in the Middle East. After the Gulf War and the liberation of Kuwait, Americans viewed the Middle Eastern states as having a status change, which is why Clinton chose to spend much of his mandate in the White House getting the Israel-Palestine conflict resolved. In short, this 
meant that the US began to watch stronger regional powers that might revolt against American leadership.

Israel was strengthened in the short term in the region after the Cold War. Syria lost the Soviet support for its army, and the PLO and Jordan suffered from economic and political damage because they supported Iraq in the Gulf War. Regional powers in Clinton's time threatened the stability of the Middle East. Therefore, his policy emphasised stability. The Carter doctrine stated that any attack against the stability of the region would be regarded as an attack on US interests. The US considered Iran and Iraq, especially as threats to regional stability. In Iran, the danger existed due to the Islamic revolution in 1979 and the fundamentalist wave it might have brought. Iran's policy in the West was perceived as expansionist and political elements were seen as directly hostile to the United States.

Iraq had approximately one million combat-trained soldiers after the ceasefire with Iran in 1988. The United States, for fear of Iran, initiated a closer relationship with Iraq beginning in the mid-eighties. The US used Iraq to counter balance Iran and ensure balance and stability in the Middle East. The same tactic had been used earlier when the United States had supported the regime in Iran until the Iranian Revolution in 1979. The idea was that the UScould steer developments in the Middle East through a surrogate state. The problem was that both Iran and Iraq had ambitions to become a regional superpower, threatening US hegemony in the Middle East. After the Gulf War, both Iran and Iraq became the most significant threats to stability and oil interests. The Clinton administration formulated thus the "dual containment" doctrine, which ensured that the two countries must not become regional superpowers. The dual containment was a response of the United States realising that it was impossible to verify their policy. Instead, the US would seek to dissuade them from being reinforced. The strategy was also an attempt to minimise Iran's influence on the Arab-Israeli peace process.

\section{The impact of US Middle East policies on the conflicts in the area}

Before we highlight the role of US Middle East politics in the conflicts in the MENA, we need to identify the mechanism for how the political decision-makers work together in an integrated climate to decide on an issue, whether it is a domestic or a foreign one.

In the United States, there is the interplay between interest groups, state bureaucracies, state legislators, the president, and Congress. Since there are so many attitudes and possible problems that can be solved, it is impossible to hear them all. That is why the mentioned groups, the Iron Triangles, often occur. Some topics may get much attention due to public interest in the topic. A policy is legitimized through public statements or actions of government officials, including the President, Congress, state legislators, government officials, and the courts. This takes place in the form of executive orders, 
budgets, laws and appropriations, rules and regulations and administrative decisions of the courts (Holsti, 2006).

An Iron Triangle consists of three links (Hayden, 2002). The first link is the senior management positions of the government. The second link is the Congress. The third link consists of the interest groups that have an interest in the problem. The participants are organized in mutually reinforcing relations between regulated interests and regulators. That is a community where each member is interdependent. The interest groups have some resources that the politicians are interested in. They can be in the form of donations to the politician and his or her campaign. Politicians provide access to the political arena, i.e. to Congress, and the Congress provides interest groups with a satisfactory solution. Together, they create an Iron Triangle, which in turn creates solutions to the problems that receive attention. In this model, AIPAC is perceived as an interest organization. AIPAC also holds a large portion of the money that politicians may well use for election campaigns, in return for some favorable choices and decisions in the policy process (Mearsheimer \& Waltz, 2008). That way, they get access to Congress through the interested politician.

\section{US policy impact on the Palestinian problem}

William Quandt explains in his book Peace Process: American Diplomacy and the ArabIsraeli Conflict since 1967 how politics and bureaucratic habits influence policymaking and implementation in regular times. However, the main point of the study is those few moments when politicians try to understand the confusing flow of events, and also when they try to connect actions with the intent behind them. Leadership capabilities and limitations are most evident.

Quandt begins by noting that since the dividing line represented by the June 1967 war, US Middle East policy has changed from an emphasis on the substance of peace to an emphasis on the process leading to peace. In some cases, the United States provided the destination and the mechanism, and that was the peace process at its best. Nevertheless, "at worst, it has been little more than a slogan used to mask the making of time" (Quandt, 2005, p. 2).

The primary American position during the period of making a deal between Arab and Israel remained remarkably consistent. In general, successive US administrations have supported the concept of exchanging land for peace, and the position that East Jerusalem is an occupied territory, and whatever its final status will be, it must not be divided again, and that settlements are at least an obstacle to peace. In this regard, the partnership with Jordan is better than an independent Palestinian state, and that Israel's military superiority must be preserved. The writer believes that the United States adheres to these positions firmly and is unlikely to change them significantly (Quandt, 2005). 


\section{The US-Egyptian relations}

The Egyptian-American relations have gone through turbulence between the years 1964-1967. According to William B. Quandt, the US considered then Egyptian president Nasser as a threat to stabilization in the region. Consequently, the US Middle East politics played a massive role in the Six-Days war between Israel and Egypt, and after the Israeli defeated the Arab armies, Israel became an essential and vital ally of the US. Also, the support shown by the US Senate for the government of Israel and its projects was one of the "encouraging" ingredients for launching the 1967 war. The US Middle East policy played an enormous role, and in the post-Nasser era and the US willingness to adopt/embrace Egypt resulted in the normalization relation between Egypt and the West. It led to the Camp David Accords between Israel and Egypt in 1978 (Quandt, 2005).

\section{The US policy impact on the Iraq-Iran War}

In the 1980s, the strategy of the United States in the Arab Gulf has changed with the emergence of the "Carter Doctrine", which was announced by the US President (Jimmy Carter) to form the deployment or rapid intervention forces in the region. Thus, the United States viewed the Iran-Iraq war as a risk to the security of oil supplies and the war of navigation, so it rushed to form the rapid intervention forces in an attempt to discourage the Soviet Union not to think of any military intervention in the region (Hersh, 1992). Moreover, despite the US administration's declaration of its neutrality in the Iraqi-Iranian war with this understanding that the war was serving it and its allies, on condition that it did not extend to other regions.

The position on the war: The United States of America sought to declare its neutrality at the outbreak of the Iraq-Iran war in 1980, although it was not linked to any of the warring parties with diplomatic relations, and the US position was due to the fact that the war did not affect the allies of the United States in the region (Donovan, 2010). However, the American position did not remain at a consistent step during the years of the war. Instead, it changed more than once as a result of the developments and results of the military battles between the two sides, and that the US policymakers did not want Iran to achieve a victory. The reason for this is that the Iranian regime did not represent a threat against the vital American component in oil supplies and the security of Israel. As for Iraq, the United States sought to support its regime and considered it is less threatening its interests, but it certainly did not want to make it a friend or an ally (Riedel, 2013).

The position of the US in the war crisis can be classified into four stages (Murray, 2014).

1. The initial stage of the war, exemplified by the relative American neutrality

2. The stage of establishment of diplomatic relations with Iraq

3. The stage of Intelligence and military support for the Iraqi government against Iran

4. The stage of US military attacks against military facilities 
The United States saw the Iraqi military superiority during the first two years of the war and the absence of diplomatic relations between it and Iraq as sufficient reasons to take a position of neutrality. Consequently, it did not have a strong justification for supporting Iraq openly and effectively, and that is what distinguished the first stage of the war, which extended from 1980 until 1983. As for the second phase, it was confined to the years 1983-1985, which was the period which witnessed a tremendous Iranian military superiority, ended up by the restoration of all the lands that Iraq controlled during the first years of the first phase. It resulted in pushing Iraq to retreat to the international borderline, which was what prompted the United States to take part in the conflict very actively without any hesitation. It fits with those developments, as it raised the level of diplomatic representation within Iraq to the level of an embassy, provided intelligence assistance and placed it at the disposal of Iraq. It also encouraged its regional allies, such as the Kingdom of Saudi Arabia and the State of Kuwait, to assist. As for the third phase, it came after Iran's occupation of the Iraqi (Al-Faw) peninsula in 1986, which was marked by the US military intervention in favor of Iraq and the beginning of the straightforward US military operations against Iran in 1988. Furthermore, with the heavy presence of helicopters and their secret reconnaissance missions in the Gulf region, and Special Forces that includes surveillance ships, made a clash with the Iranian forces unavoidable (Woods, Murray, \& Mounir, 2009).

As for the fourth stage, it started from the fall of the year 1986 until the spring of the year 1988, and at that stage, the United States found that its position in support of Iraq during the previous stages did not contribute to making a significant change in Iran, so the American naval forces attacked Iran.

\section{Conclusion}

In conclusion, this study has tracked the Middle East policy of the successive American administrations from Truman to Bush, Sr., in the interest of Israel. The end of WWII led to the emergence of a new world order that obliged the United States to involve itself in the Middle East. This involvement occurred as a combination of a desire to guarantee access to oil flow, protect Israel, contain the influence of the Soviet Union, and secure regional stability in the Middle East. These factors used to maintain a balance of power against the Soviet Union until the fall of the Berlin Wall in 1989 and subsequently the fall of the Soviet Union.

After the Cold War ended and the world transitioned to uni-polarity, Israel was still a driving interest behind American foreign policy. US' unconditional support for Israel indirectly had a negative influence on the Middle East countries. Moreover, the US role in the wars that Israel waged against its Arab neighbours has contributed negatively to the American image in the Arab world and the Middle East. The reason for continued US interest in Israel goes back to the Jewish lobby being highly influential in US foreign policy. It is also in light of this that we must understand the US desire to see 
the other Middle Eastern countries accept Israel as a state, which was reflected in its efforts to spark a continuous peace process. Another turning point in the Middle East was Iraq's invasion of Kuwait. This invasion has allowed Americans to establish their military bases on Muslim soil in Saudi Arabia. The US presence in Saudi Arabia was used to radicalize a large group of young Muslims against both American hegemony and Arab defeatist regimes. Young Arab radicalists would see their leaders as servants of America. A combination of historical and current conflicts have had a broad impact on the population in the Arab World, and it is this combination that the researchers think is the reason for the mass dissatisfaction with the US policy of today, considered to be a biased policy that we are experiencing in the Middle East today.

\section{References}

1. Anders, B., Fredrik, B., Oyyind, T. G., \& Torbjorn, S. (2008). American culture: An anthology. New York: Routledge.

2. Andersen, L. E. (2003). Den Amerikanske orden - USA og det moderne Mellemøsten [The US policy - united states and the modern Middle East]. København: Aschehoug.

3. Ashton, N. J. (2007). The Cold War in the Middle East. Abingdon: Routledge.

4. Bar-Siman-Tov, Y. (1998). The United States and Israel since 1948: A "special relationship". Diplomatic History, 22(2), 231-262.

5. Bowcott, O. (2004). UK feared Americans would invade Gulf during 1973 oil crisis. The Guardian. Retrieved from http://www.guardian.co.uk/politics/2004/jan/01/ uk.past3.

6. Branner, H. (2002). Det Nye Europa: International politik i forandring (The New Europe: International politics in transition). Copenhagen: Columbus.

7. Chomsky, N. (2003). Power and terror: Post-9/11 talks and interviews. New York: Seven Stories Press.

8. Cobban, H. (1989). The US-Israeli Relationship in the Reagan Era. The Journal of Conflict Studies, 9(2), 5-32.

9. Donovan, J. (2010). The Iran-Iraq War: Antecedents and Conflict Escalation. New York: Routledge.

10. Galster, S. (2001). Afghanistan: Lessons from the last war. Washington: Washington University's National Security Archive.

11. Gettleman, M. E., \& Schaar, S. (2003). The Middle East and Islamic world reader. New York: Grove Press.

12. Hayden, G, F. (2002). Policymaking Network of the Iron-Triangle Subgovernment for Licensing Hazardous Waste Facilities. Journal of Economic Issues, vol. XXXVI, no. 2.

13. Herrmann, R. K. (1994). Russian policy in the Middle East: Strategic change and tactical contradictions. Middle East Journal, 48(3), 455-474.

14. Hersh, S. (1992). US Secretly Gave Aid to Iraq Early in Its War Against Iran. The New York Times. Retrieved from https://www.nytimes.com/1992/01/26/world/us-secretlygave-aid-to-iraq-early-in-its-war-against-iran.html. 
15. Holsti, 0. (2006). Making American Foreign policy. New York: Routledge.

16. Jerichow, A. (1993). Mellemøsten i 90'erne [The Middle East in 90th]. Copenhagen: Borgen.

17. Klare, M. T. (1992). US military policy in the post-Cold War era. The Socialist Register, 28, 131-142.

18. Lockman, Z. (2004). Contending visions of the Middle East: The history and politics of Orientalisem. Cambridge: Cambridge University Press.

19. Mearsheimer, J., \& Walt, S. (2008). Israel Lobby and US Foreign Policy. New York: FSG Adult.

20. Murray, W. (2014). The Iran-Iraq War: A Military And Strategic History. Cambridge: Cambridge University Press.

21. Nasir al-Sabah, S. S. (1990). Kuwait's approach to the Gulf crisis. The Washington Institute. Retrieved from https://www.washingtoninstitute.org/policy-analysis/view/ kuwaits-approach-to-the-gulf-crisis.

22. Nauntofte, J. (1987). USA og Mellemøsten [USA and the Middle East]. Copenhagen: Jurist og Økonomiforbundets Forlag.

23. Nielsen, F. (2003). With God on our side. Omaha: University of Nebraska.

24. Nye, J. (2014, February 10). The myth of isolationist of America. Project Syndicate. Retrieved from https://www.project-syndicate.org/commentary/joseph-s--nye-refu tes-the-increasingly-widespread-view-that-the-us-is-turning-inward?barrier=acces spaylog.

25. Olsen, G. R. (1991). Golfkrisenog den nyeverdensorden [The Gulf crisis and the new world order]. Copenhagen: Security and Disarmament Policy Committee.

26. Ougaard, M. (1992). USA's hegemoni og den ny verdensorden. Politica, 24(2), 132.

27. Riedel, B. (2013, May 22). Lessons from America's First War with Iran. Brookings. Retrieved from https://www.brookings.edu/articles/lessons-from-americas-first-warwith-iran/.

28. Rose, G. (2001). Review: Democracy Promotion and American Foreign Policy: A Review Essay. International Security, 25(3), 186-203.

29. Robby, F, H. (2020). Arab Nationalism: Past, Present, Future. Journal of Integrative International Relations, 5(1), 1-32.

30. Roslyng-Jensen, P. (2003). Fra kold krig til ny verdensorden [From the cold war to the new world order]. Copenhagen: Gyldendal.

31. Quandt, W. (2005). Peace Process: American Diplomacy and the Arab-Israeli Conflict since 1967. Washington and Berkeley: Brookings Institution Press and the University of California Press.

32. Rubin, B. (1979). Anglo-American Relations in Saudi Arabia, 1941-45. Journal of Contemporary History, 14(2), 253-267.

33. Rubin, B. (2002). The Real Roots of Arab Anti-Americanism. Foreign Affairs. Retrieved from http://www.foreignaffairs.org/20021101faessay9993/barry-rubin/the-real-roo ts-of-arab-anti-americanism.html. 
34. Simbar, R. (2006). Iran and the US: Engagement or Confrontation. Journal of International and Area Studies. 13(1), 73-87.

35. Spiegel, S. L. (1985). Other Arab-Israeli Conflict: Making America's Middle East policy from Truman to Reagan. Chicago: University of Chicago Press.

36. Spiller, R. J. (1981). "Not war but like war": The American intervention in Lebanon. Fort Leavenworth: Combat Studies Institute.

37. Woods, K. Murray, W., \& Mounir, K. (2009). Saddam's War: An Iraqi Military Perspective of the Iran-Iraq War. Washington: National Defense University.

38. Yaqub, S. (2006). Containing Arab nationalism: The Eisenhower doctrine and the Middle East. North Carolina: The University of North Carolina Press.

39. Zunes, S. (2002). US Aid to Israel: Interpreting the "strategic relationship". AlJazeerah. Retrieved from http://www.aljazeerah.info/Documents/U.S.\%20Aid\%20to\%20Israel. htm. 